\title{
EFFECT OF WHEAT (Triticum aestivum L.) GENOTYPES ON PROXIMATE COMPOSITION
}

\author{
S.M.R. Islam ${ }^{1}$, K.U. Ahmed ${ }^{1}$, M.U. Miah ${ }^{1}$ and M. Mostofa ${ }^{2^{*}}$ \\ ${ }^{1}$ Department of Biochemistry, Faculty of Agriculture \\ ${ }^{2}$ Institute of Seed Technology \\ Sher-e-Bangla Agricultural University, Dhaka, Bangladesh
}

\begin{abstract}
The experiment was conducted during the period from November 2015 to June 2016 at the Laboratory of Biochemistry Department, Sher-e-Bangla Agricultural University (SAU) and Soil Science Laboratory of Bangladesh Agriculture Research Institute (BARI), to find out the effect of different wheat (Triticum aestivum L.) genotypes on proximate composition. Six wheat genotypes, i.e., BARI Gom 25, BARI Gom 26, BARI Gom 27, WYCYT (E-15) (Line), WYCYT (E-16) (Line) and PAVON-76 (Local) were used as a treatment for the experiment. The highest weight of 1000 grains, dry matter content, carbohydrate content, protein content, lipid content, ash content were recorded from BARI Gom 26 (46.45 g), BARI Gom 27 (92.53\%), WYCYT (E-16) (69.59\%), BARI Gom 27 (10.08\%), BARI Gom 26 (2.20\%), BARI Gom 26 (2.38\%), respectively. Nevertheless, the lowest weight of 1000 grains, dry matter content, carbohydrate content, protein content, lipid content, ash content were recorded from PAVON-76 (Local) (39.25 g), WYCYT (E-15) (Line) (90.43\%), BARI Gom 26 (64.87\%), WYCYT (E-16) (Line) (9.5\%), WYCYT (E-16) (Line) (1.74\%), WYCYT (E16) (Line) (1.86\%), respectively.
\end{abstract}

Keywords: Genotypes, Nutrient composition, Wheat

\section{INTRODUCTION}

Wheat (Triticum aestivum L.) is the most important cereal crop available all over the world and in even higher demand in recent years due to its superior health benefits. It occupies 17 percent of the total cultivated land in the world and it is the staple food for 35 percent of the world's population (IDRC, 2019). The total world wheat production was 771.7 million metric tons in the year 2017 and China is the top wheat-producing country in the world (FAOSTAT, 2019). Bangladesh is a subtropical country where wheat is the second largest cereal crop and grown in a short winter spell that being in November and ends in the first week

\footnotetext{
* Corresponding Author: marufsau@ hotmail.com
} 
of March in southwestern part and third week of March in the northern region. At present, about 415,339 hectares of land in Bangladesh are covered by wheat, with the annual production of 13,11,473 metric tons in the year 2017 (FAOSTAT, 2019).

Wheat belongs to the genus Triticum, of the family Poaceae also known as Gramineae. It originated in Southwest Asia, Tigris and Euphrates river valley, in the area known as the Fertile Crescent (Smith and Wayne, 1995). The area and yield of wheat have been increasing dramatically based on the demand of over increasing population of Bangladesh during the last two decades.

Wheat Research Centre (WRC) and Bangladesh Agricultural Research Institute (BARI) have released 30 improved wheat varieties. But many of those were not adequately adopted by farmers. Inadequate knowledge, lack of specifically adapted varieties and inadequate extension efforts are an important reason for this. Wheat is grown under a wide range of climatic and soil conditions and it grows well in clay loam soils. It is a crop of Rabi season (winter season), requires dry weather in Bangladesh. Well distributed rainfall between 40 and $110 \mathrm{~cm}$ is suitable for wheat's growth. Almost 100-120 days are required from sowing to harvest in Bangladesh.

Wheat is a rich source of carbohydrate and also contain protein, fat, ash, fiber, vitamins as well as mineral such as sodium, potassium, calcium, magnesium, iron, phosphorus, copper, zinc and manganese (Kumar et al., 2011). Wheat is unique among cereals. It contains gluten which has the characteristic of being elastic when mixed with water and retains the gas developed during dough fermentation. The wheat flour containing a large amount of protein and high quality of gluten is used for normal bread. The lower amount of protein in wheat is mostly used for confectionery or cakes (Caballero et al., 2007). Wheat produced in different parts of the world differ greatly in their intrinsic protein qualities and quantities; the quantity is influenced mainly by environmental factors. But the quality of protein is mainly a heritable characteristic (Bordes et al., 2008).

Wheat is one of the most important cereals cultivated worldwide. Wheat flour is used to produce bread, noodles, pasta and a wide range of other food products (Tosi et al., 2011). Characteristics of wheat in terms of physiological characteristics and also mineral contents depend on cultivar and other environmental factors and the interaction between cultivar and environment (Panozzo and Eagles, 2000).

Firstly, two Mexican varieties ('Sonora 64' and 'Penjamo 62') were tested in the northern part of Bangladesh (BARI, 2010) and their spectacular performance encouraged scientists to introduce more wheat varieties (BARI, 1993).The physicochemical characteristics and related nutritional values are the utmost necessity of wheat consumers. The objective of the study was to evaluate the physicochemical parameters of different wheat genotypes. 


\section{MATERIALS AND METHODS}

\section{Experimental location}

To find out the effect of different wheat genotypes on proximate composition, a laboratory experiment was conducted from during November 2015 to June 2016. The experiment was carried out at the Laboratory of Biochemistry Department, Sher-eBangla Agricultural University (SAU) and Soil Science Laboratory of Bangladesh Agriculture Research Institute (BARI).

\section{Experimental material}

Four (4) released and two (2) advanced lines of wheat were used as experimental materials for study. Genotypes are BARI Gom 25, BARI Gom 26, BARI Gom 27, WYCYT (E-15) (Line), WYCYT (E-16) (Line) and PAVON-76 (Local). Wheat genotypes were used as treatment in the experiment are presented in Figure 1.

\section{Brief Description of wheat genotypes}

i. BARI Gom 25: It is semi-dwarf and height with high yielding variety evolved by Bangladesh Agriculture Research Institute (BARI) in 2010. Gains are glossy and larger in size.

ii. BARI Gom 26: It is a semi-dwarf in height with high yield potential variety evolved by BARI in 2010. Grains are amber in color, bright and larger in size.

iii. BARI Gom 27: It is a high yielding, short stature variety evolved by BARI in 2012. Grains are white amber in color and medium in size.

iv. WYCYT (E-15) (Line): It is an advanced line of Wheat variety and evolved by BARI.

v. WYCYT (E-16) (Line): It is another advanced line of Wheat variety and evolved by BARI.

vi. PAVON-76 (Local): It is a local variety evolved by BARI in 1979 and cultivated in the different Wheat-growing areas of Bangladesh.

\section{Data Collection}

The chemical analysis was done at the Laboratory of Biochemistry Department, Sher-e-Bangla Agricultural University (SAU) and Soil Science laboratory of Bangladesh Agriculture Research Institute (BARI).

\section{Determination of 1000 grains weight}

After threshing, a random sample of fully grown 1000 seeds were counted and weighed at $14 \%$ moisture content. The collected one thousand wheat grains were weighed by using a digital electric balance and expressed in gram (g). 


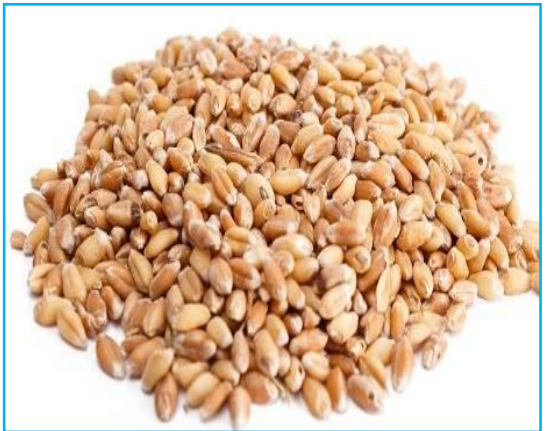

BARI Gom 25

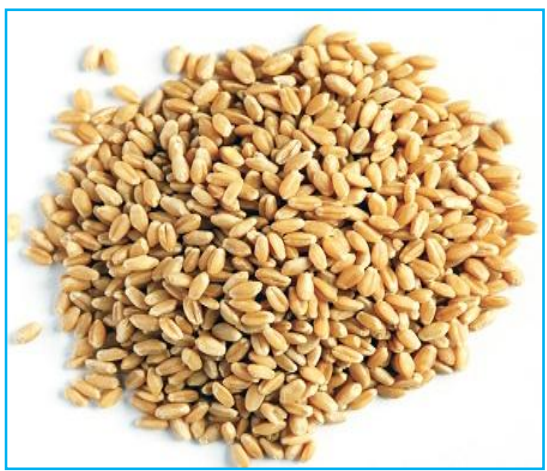

BARI Gom 27

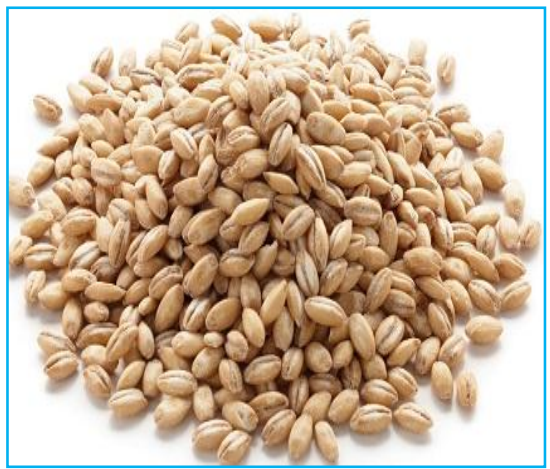

WYCYT (E-16)

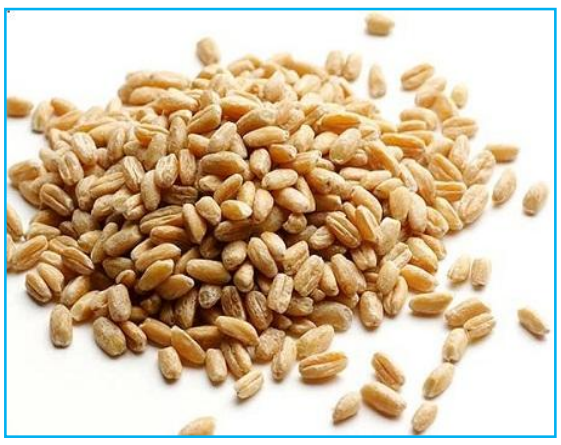

BARI Gom 26

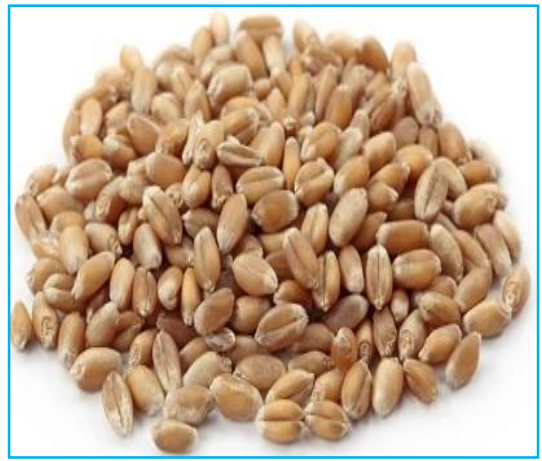

WYCYT (E-15)

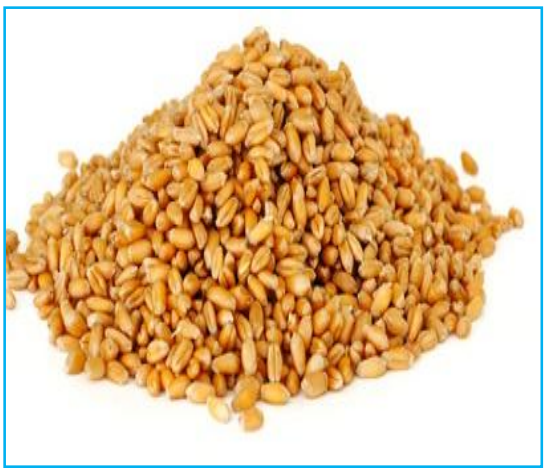

PAVON-76

Figure 1. Photograph showing wheat genotypes were used as treatment in the experiment 


\section{Determination of Dry matter}

A clean dish was placed in an oven at $105^{\circ} \mathrm{C}$ overnight. After cooling the dish in desiccators was weighed. After taking the sample in the dish, the dish was weighed. Then it was placed in the oven at $105^{\circ} \mathrm{C}$ for $24 \mathrm{~h}$. With sample after cooling the dish in desiccators was weighted. Again, the dish was placed in the oven at $105^{\circ} \mathrm{C}$ for 2 hours. It was cooled in desiccators and weighed again. Repeated drying, cooling and weighing until the weight became constant. The dried sample was stored in an airtight dish. The moisture content of the sample was calculated and dry matter was determined by subtracting the moisture content from fresh samples. The estimated dry matter was expressed as percent (\%).

\section{Proximate composition}

The oven-dried wheat was grinded in a grinder and filtered with a suitable strainer. It was necessary to dry the sample in the oven at $105^{\circ} \mathrm{C}$ overnight. Then the wheat grains sample was ready for measuring proximate composition. The content of available total carbohydrate, total protein, total lipid, total ash and total crude fiber were estimated as g per $100 \mathrm{~g}$ dried sample as described by Raghuramulu et al. (2003).

\section{Statistical Analysis}

The recorded data for each character from the experiments were statistically analyzed to find out the significant difference of different wheat genotypes in respect of proximate composition. The mean values of all the characters were calculated and analysis of variance of characters under the study was performed by the ' $F$ ' (variance ratio) test. The significant difference of the treatment means was calculated by Duncan's Multiple Range Test (DMRT) at 5\% level of probability.

\section{RESULTS AND DISCUSSION}

\section{Weight of 1000 grains}

Weight of 1000 grains of wheat genotypes were found statistically significant. It revealed that the highest weight of 1000 grains were recorded from BARI Gom 26 (46.45 g), which was statistically similar to BARI Gom 25 and WYCYT (E-15) (Line), and closely followed by BARI Gom 27, whereas, the lowest weight of 1000 grains were recorded from PAVON-76 (Local) (39.25 g), which was statistically similar to WYCYT (E-16) (Line) (41.45 g) genotypes (Table 1). Generally, the weight of grains is a genetical character. It is controlled by the genetic makeup of the genotypes. Different genotypes produced different size and weight of grains. Apart from management practices genetic make-up influences weight of 1000 grains. AlMusa et al. (2012) reported that among the BARI varieties, BARI Ghom-26 produced a higher weight of 1000 grains (49.38 g). Mohsen et al. (2013) observed that that the effect of cultivars was significant for all wheat parameters, including 1000 grains weight. 


\section{Moisture}

Statistically significant variation was recorded in terms of moisture content due to three released, two advanced lines and one local wheat genotypes. The highest moisture content was found from WYCYT (E-15) (Line) (9.64\%), which was statistically similar to PAVON-76 (Local), WYCYT (E-16) (Line) and BARI Gom 25. On the other hand, the lowest moisture content was found from BARI Gom 27 (7.54\%) which was statistically similar to BARI Gom 26 (7.90\%) (Table 1).

\section{Dry matter}

Different wheat genotypes showed statistically significant variation for dry matter content. The highest dry matter content were observed from BARI Gom 27 (92.53\%), which was statistically similar to BARI Gom 26 (92.17\%), while the lowest dry matter content was found from WYCYT (E-15) (Line) (90.43\%) which was statistically similar to PAVON-76 (Local), WYCYT (E-16) (Line) and BARI Gom 25, respectively (Table 1). Mahmoud et al. (2015) reported high values of dry matter $(87.37 \mathrm{~g} / 100 \mathrm{~g} \mathrm{FW})$ in different genotypes of wheat.

Table 1. Weight of 1000 grains, moisture and dry matter content of different released variety, advanced lines and local variety of wheat

\begin{tabular}{lccc}
\hline \multicolumn{1}{c}{$\begin{array}{c}\text { Name of Wheat } \\
\text { genotypes }\end{array}$} & Weight of 1000 seeds (g) & Moisture (\%) & Dry matter (\%) \\
\hline BARI Gom 25 & $45.78 \mathrm{a}$ & $9.03 \mathrm{a}$ & $91.04 \mathrm{~b}$ \\
BARI Gom 26 & $46.45 \mathrm{a}$ & $7.90 \mathrm{~b}$ & $92.17 \mathrm{a}$ \\
BARI Gom 27 & $42.98 \mathrm{bc}$ & $7.54 \mathrm{~b}$ & $92.53 \mathrm{a}$ \\
WYCYT (E-15) (Line) & $44.38 \mathrm{ab}$ & $9.64 \mathrm{a}$ & $90.43 \mathrm{~b}$ \\
WYCYT (E-16) (Line) & $41.45 \mathrm{~cd}$ & $9.17 \mathrm{a}$ & $90.90 \mathrm{~b}$ \\
PAVON-76 (Local) & $39.25 \mathrm{~d}$ & $9.35 \mathrm{a}$ & $90.72 \mathrm{~b}$ \\
\hline LSD $(0.05)$ & 2.617 & 0.837 & 1.075 \\
CV (\%) & 3.51 & 5.89 & 4.29 \\
Significance level & $* *$ & $* *$ & $* *$ \\
\hline
\end{tabular}

In a column means having similar letter(s) are statistically identical and those having dissimilar letter(s) differ significantly as per 0.05 level of probability.

\section{Carbohydrate}

Statistically, significant variation was recorded in terms of carbohydrate content due to different wheat genotypes. The highest carbohydrate content was observed from WYCYT (E-16) (Line) (69.59\%), which was statistically similar to WYCYT (E-15) (Line) and PAVON-76 (Local), respectively and followed by BARI Gom 25, whereas the lowest carbohydrate content was found from BARI Gom 26 (64.87\%), 
followed by BARI Gom 27 (Table 2). Carbohydrate is the main component in wheat grain (54-72\% of dry grain weight) and it affects the texture of baked products. It consists of $20-25 \%$ of the linear molecule, amylose and $75-80 \%$ of complex and highly branched molecule amylopectin (Stone et al., 2009).

\section{Protein}

Statistically, significant variation was recorded due to different wheat genotypes in terms of protein content. The highest protein content were found from BARI Gom 27 $(10.08 \%)$ which was statistically similar to BARI Gom 26 and followed by BARI Gom 25, whereas the lowest protein content was recorded from WYCYT (E-16) (Line) (9.5\%) which was statistically similar to WYCYT (E-15) (Line) and PAVON76 (Local), respectively (Table 2). Protein is an essential constituent that determines the bread-making quality (Pomeranz, 1987; Shewry, 2009). Protein content in fully matured wheat grain varied from 10-20\% (Shewry et al., 1994) and assumed that $10 \%$ protein content in wheat grains.

\section{Lipid}

Lipid content exhibited statistically significant variation due to different wheat genotypes. The highest lipid content was recorded from BARI Gom 26 (2.20\%) which was statistically similar to BARI Gom 27 and closely followed by PAVON-76 (Local). The lowest lipid content was observed from WYCYT (E-16) (Line) (1.74\%) which was statistically similar to WYCYT (E-15) (Line) and BARI Gom 25, respectively (Table 2). Wieser (2007) reported high values of lipid $(2.18 \%$ ) in different genotypes of wheat.

\section{Ash}

Different wheat genotypes varied significantly in terms of ash content. The highest ash content was recorded from BARI Gom 26 (2.38\%), which was statistically similar to BARI Gom 27, PAVON-76 (Local) and BARI Gom 25, while the lowest ash content was recorded from WYCYT (E-15) (Line) (1.86\%), which was statistically similar by WYCYT (E-16) (Line) (Table 2). Mahmoud et al. (2015) reported high values of ash content $(3.08 \mathrm{~g} / 100 \mathrm{~g} \mathrm{FW})$ in different genotypes of wheat.

\section{Crude fiber}

Crude fiber showed statistically significant differences in terms of content due to different wheat genotypes. The highest crude fiber content was recorded from BARI Gom $26(15.09 \%)$ which was statistically similar to BARI Gom 27 and BARI Gom 25 , respectively and followed by WYCYT (E-15) (Line). On the other hand, the lowest crude fiber content was recorded from WYCYT (E-16) (Line) (13.33\%) which was statistically similar by PAVON-76 (Local) genotypes (Table 2). Wieser (2007) reported that high-value crude fibers $(15.22 \%)$ in different genotypes of wheat. 
Table 2. Carbohydrate, protein, lipid, ash and crude fiber content of different released variety, advanced lines and local variety of wheat

\begin{tabular}{lccccc}
\hline $\begin{array}{c}\text { Name of Wheat } \\
\text { genotypes }\end{array}$ & $\begin{array}{c}\text { Carbohydrate } \\
(\%)\end{array}$ & $\begin{array}{c}\text { Protein } \\
(\%)\end{array}$ & Lipid (\%) & $\begin{array}{c}\text { Ash } \\
(\%)\end{array}$ & $\begin{array}{c}\text { Crude fiber } \\
(\%)\end{array}$ \\
\hline BARI Gom 25 & $67.43 \mathrm{bc}$ & $9.71 \mathrm{ab}$ & $1.81 \mathrm{~cd}$ & $2.06 \mathrm{a}$ & $14.84 \mathrm{abc}$ \\
BARI Gom 26 & $64.87 \mathrm{~d}$ & $9.87 \mathrm{ab}$ & $2.20 \mathrm{a}$ & $2.38 \mathrm{a}$ & $15.09 \mathrm{a}$ \\
BARI Gom 27 & $66.30 \mathrm{c}$ & $10.08 \mathrm{a}$ & $2.02 \mathrm{ab}$ & $2.36 \mathrm{a}$ & $14.91 \mathrm{ab}$ \\
WYCYT (E-15) & $68.102 \mathrm{ab}$ & $10.05 \mathrm{a}$ & $1.80 \mathrm{~cd}$ & $1.86 \mathrm{~b}$ & $14.22 \mathrm{bc}$ \\
WYCYT (E-16) & $69.59 \mathrm{a}$ & $9.5 \mathrm{~b}$ & $1.74 \mathrm{~d}$ & $1.97 \mathrm{~b}$ & $13.33 \mathrm{c}$ \\
PAVON-76 (Local) & $68.56 \mathrm{ab}$ & $9.78 \mathrm{ab}$ & $1.88 \mathrm{bcd}$ & $2.17 \mathrm{a}$ & $13.80 \mathrm{c}$ \\
\hline LSD (0.05) & 1.475 & 1.449 & 0.246 & 0.343 & 1.351 \\
CV (\%) & 4.07 & 5.77 & 3.28 & 3.10 & 3.97 \\
Significance level & $* *$ & $*$ & $*$ & $* *$ & $*$ \\
\hline
\end{tabular}

In a column means having similar letter(s) are statistically identical and those having dissimilar letter(s) differ significantly as per 0.05 level of probability.

\section{CONCLUSION}

A nutritional analysis is important for breeders to evolve more nutrient rich Wheat genotypes. Further analysis of different wheat genotypes should be done to know their nutritional value. Chemical composition and nutritional traits give the future strategy for the nutritionist, health advisor and dietician to know how to develop best use of the wheat.

\section{REFERENCES}

Al-Musa, M.A.A., Ullah, M.A., Moniruzzaman, M., Islam, M.S. and Mukherjee, A. (2013). Effect of BARI wheat varieties on seed germination, growth and yield under Patuakhali district. Journal of Environmental Science and Natural Resources, 5(2): 209-212.

BARI. (2010). Wheat production in Bangladesh: a success story. Bangladesh Agricultural Research Institute. http://www.bari.gov.bd/

BARI. (1993). Annual Report (1991-92). Bangladesh Agricultural Research Institute, Joydebpur, Gazipur-1701. Pp.19-33.

BMD. (2016). Bangladesh Meteorological Department, Agargaon, Dhaka-1207, Bangladesh. http://www.bmd.gov.bd/

Bordes, J., Branlard, G., Oury, F.X.,Charmet, G. and Balfourier, F. (2008). Agronomic characteristics, grain quality and flour rheology of 372 bread wheat in a worldwide core collection. Journal of Cereal Science, 48(3): 569-579.

Caballero, P.A., Gomez, M. and Rosell, C.M. (2007). Improvement of dough rheology, bread quality and bread shelf-life by enzymes combination. Journal of Food Engineering, 81(1): 42-53. 
FAOSTAT. (2019). Statistical Database. Food and Agricultural Organization of United Nations, Rome, Italy.

IDRC. (2019). Facts \& figures on food and biodiversity. International Development Research Centre. https://www.idrc.ca/en/research-in-action/facts-figures-food-and-biodiversity

Kumar, P., Yadava, R.K., Gollen, B., Kumar, S., Verma, R.K. and Yadav, S. (2011). Nutritional contents and medicinal properties of wheat: a review. Life Sciences and Medicine Research, 22: 1-10.

Mahmoud, A.A., Mohdaly, A.A.A. and Elneairy, N.A.A. (2015). Wheat germ: An overview on nutritional value, antioxidant potential and antibacterial characteristics. Food and Nutrition Sciences, 6(2): 265-277.

Mohsen, A., Mahmood, M.I. and Hassan, H.A.R. (2013). Effects of sowing dates on growth and yield components of different Wheat cultivar. Journal of Agricultural Science, 4(11): 11-19.

Panozzo, J.F. and Eagles, H.A. (2000). Cultivar and environmental effects on quality characters in wheat. II. protein. Australian Journal of Agricultural Research, 51(5): 629-636.

Pomeranz, Y. (1987). Bread around the world. Modern Cereal Science and Technology. VCH Publishers Inc., New York, NY. Pp. 258-333.

Raghuramulu, N., Madhavan, N.K. and Kalyanasundaram, S. (2003). A manual of laboratory techniques. National Institute of Nutrition. Indian Council of Medical Research, Hyderabad-500007, India. Pp. 56-58.

Smith, C. and Wayne. (1995). Crop Production. John Wiley and Sons. Pp. 60-62.

Shewry, P.R. (2009). Wheat. Journal of Experimental Botany, 60(6): 1537-1553.

Shewry, P.R., Tatham, A.S., Halford, N.G., Barker, J.H., Hannappel, U., Gallois, P., Thomas, M. and Kreis, M. (1994). Opportunities for manipulating the seed protein composition of wheat and barley in order to improve quality. Transgenic Research, 3(1): 3-12.

Stone, B. and Morell, M.K. (2009). Carbohydrates. In: Wheat: Chemistry and Technology. Pp. 299-362.

Tosi, P., Gritsch, C.S., He, J. and Shewry, P.R. (2011). Distribution of gluten proteins in bread Wheat (Triticum aestivum) grain. Annals of Botany, 108(1): 23-35.

Wieser, H. (2007). Chemistry of gluten proteins. Food Microbiology, 24(2):115-119.

WRC. (2003). Annual Report. 2002-2003. Wheat Research Centre, Bangladesh Agricultural Research Institute, Nashipur, Dinajpur. Pp.6-36.

WRC. (2009). Annual Report, 2008-09. Wheat Research Center, Nashipur, Dinajpur, Bangladesh. Pp.1-181. 